\title{
Chapter 9 \\ The Practice of Education for Disaster \\ Risk Reduction in Vietnam: Lessons \\ Learned from a Decade of Implementation 2010-2020
}

\author{
Thi Thi My Tong, Duong Thi Hong Nguyen, Hung The Nguyen, \\ and Tae Yoon Park
}

\subsection{Introduction}

The increasing damage caused by natural disasters, particularly climatic disasters such as typhoons, floods, droughts, and heatwaves, threatens the development of all economic sectors in Vietnam. In particular, the impact of natural disasters on the education sector affects thousands of students and teachers, because it interrupts their education and significantly reduces educational quality. At the same time, education is increasingly being viewed as more essential for mitigating risk and for strengthening people's capacity to respond to disasters. Disaster risk reduction education (DRRE) initiatives have become more widely adopted among international and national organizations. The importance of disaster risk reduction (DRR) is currently a major concern of the United Nations, and has resulted in the establishment of numerous initiatives such as the International Decade for Natural Disaster Reduction, the International Framework for Action for the International Decade for Natural Disaster Reduction, the Yokohama Strategy, the Plan of Action for a Safer World adopted by the 1st World Conference on Natural Disaster Reduction (UNISDR 2004), the International Strategy for Disaster Reduction, and the adoption of the Hyogo Framework for Action at the 2nd World Conference on Disaster Reduction in 2005 (UNISDR 2005). The role of education was highlighted as an

\footnotetext{
T. T. M. Tong $(\bowtie) \cdot$ D. T. H. Nguyen

Vietnam Institute of Economics, Vietnam Academy of Social Science, Hanoi, Vietnam

H. T. Nguyen

Department of Climate Change and Sustainable Development, Hanoi University of Natural

Resource and Environment, Hanoi, Vietnam

T. Y. Park

Graduate School of Education, Yonsei University, Seoul, South Korea
}

T. Ito et al. (eds.), Interlocal Adaptations to Climate Change in East and Southeast Asia, SpringerBriefs in Climate Studies, https://doi.org/10.1007/978-3-030-81207-2_9 
important strategy for achieving the four priorities set out in the Sendai Framework for Disaster risk reduction 2015-2030 (UNFCCC 2015).

Vietnam was ranked sixth among countries most affected by extreme climatic events in 1999-2018 by the Global Climate Risk Index (David Eckstein 2019). The country frequently experiences severe and unpredictable climatic events, and it is estimated that these will likely become worse under the RCP4.5 scenario as the average temperature, rainfall and sea-level rise increase by $0.1{ }^{\circ} \mathrm{C}, 5-15 \%$, and 20\%, respectively (MONRE 2016).

With the proportion of children making up almost a quarter of Vietnam's population, an increase in the intensity of natural disasters and climate change will have a considerable impact on their development. Children are always the group most affected by natural disasters due to their physical and psychosocial vulnerability, as well as their lack of access to essential services such as health and education. In this context, DRRE is considered to be an essential strategy for sustainable development in the long-term. DRRE initiatives will better prepare children, families, and communities for shocks and significant recovery. Consequently, investing in risk reduction measures in schools is considered to be fundamental to social growth, development, and cohesion in Vietnam and for achieving the Sustainable Development Goals.

Since the beginning of the 2010s, numerous education projects on climate change response and DRR have been conducted throughout Vietnam. Most of these projects promote two main initiatives; making schools safer, and mainstreaming climate change and DRR into the school curriculum. In 2011, the Ministry of Education and Training (MOET) published the Action Plan on implementing National Strategy for Natural Disaster Prevention, Response, and Mitigation to 2020 (MOET 2011). This plan has facilitated the development of content on climate change and DRR for use in the national curriculum of public schools. In 2014, the Ministry of Education approved the project "Information and propaganda on climate change response and natural disaster prevention and control in schools in the period 2013-2020". In 2016, specific guidance for carrying out DRRE in schools was developed and applied nationwide (MOET 2016).

Within this context, this study attempts to review the DRRE initiatives over one decade of implementation (2010-2020). The findings will clarify the lessons learned from DRRE by various stakeholders, including government and non-governmental organizations.

\subsection{DRRE Initiatives in Vietnam}

DRRE arose out of a long history of coping with natural disasters in Vietnam. The local communities have prepared for, responded to, and recovered from natural disasters using their wisdom and knowledge, which they passed from one generation to the next. In some ways, these indigenous practices can be seen as one of the 
first examples of DRRE and they are considered to be a valuable source of information to communities and schools on DRR.

Before the National Action Plan on DRR was adopted by the education sector, DRRE initiatives were mainly implemented by NGOs and other organizations outside the government. According to a mapping exercise that collected information regarding projects and programs on communication and education related to climate change and DRR by Live and Learn in Vietnam (Live and Learn Vietnam 2012), more than $50 \%$ of the programs and projects were implemented by INGOs and NGOs in Vietnam (Fig. 9.1). The topic focused mainly on climate change education (52\%), DRR (28\%), and a combination of both themes (20\%) (Live and Learn Vietnam 2012) (Fig. 9.2).

The following section will describe 14 programs and projects conducted by MOET, NGOs, and other organizations. The findings showed that DRRE in schools covered or integrated activities on school facilities/building safety, injury prevention, swimming lessons, extracurricular activities (such as disaster prevention drills or competitions), environmental protection activities, the integration of DRR into the curriculum (such as the development of reference books for students and teaching materials for teachers, and training for teachers and students), and raising awareness in the community and among parents. Projects and programs conducted by MOET and government agencies focused on the safety of school facilities/school buildings and the development of teaching and learning materials related to DRR. In addition, DRRE activities conducted by NGOs and other organizations focused mainly on extracurricular activities and raising awareness in the community and among parents (Table 9.1).

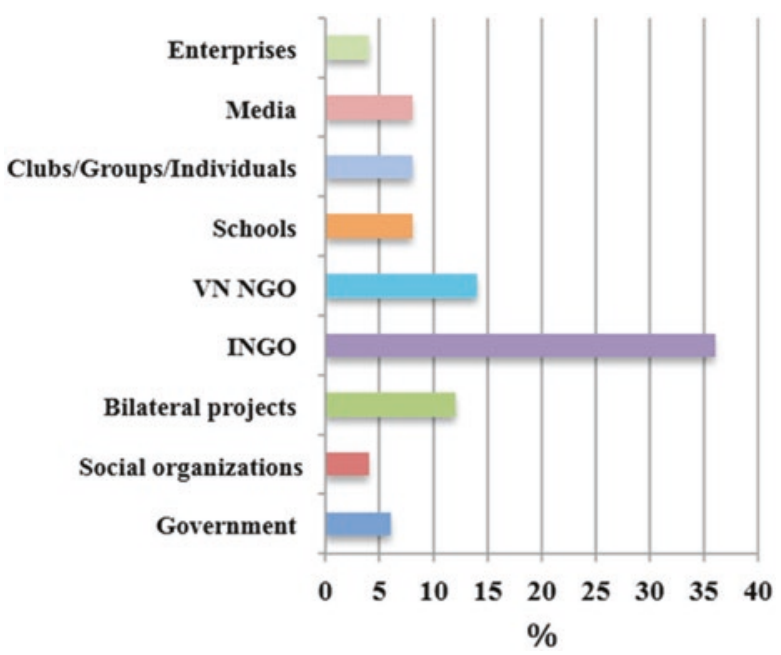

Fig. 9.1 Proportion of organizations that adopted DRRE initiatives. (Source: Live and Learn Viet Nam 2012) 


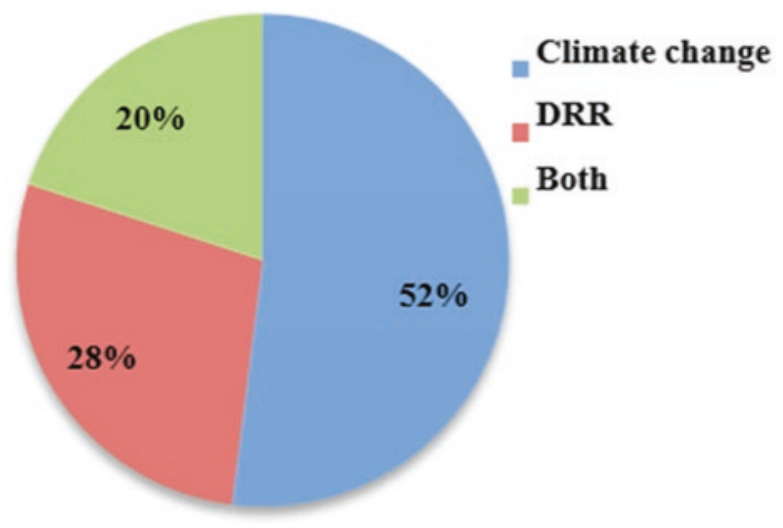

Fig. 9.2 Topics of DRRE initiatives. (Source: Live and Learn Viet Nam 2012)

\subsubsection{Governmental Programs}

\subsubsection{Initiatives by the MOET}

At the national level, every year, the MOET has prepared instructional materials on the preparation for, and action response to, disasters. These materials are typically issued at the beginning of the academic year or at the beginning of the disaster seasons to remind schools, educational institutions, and other educational offices about disaster prevention, response, and recovery. In 2008, the MOET initiated the ChildFriendly School program from primary to secondary level, which laid the foundation for effective DRRE implementation. One of the program's salient features was to target the provision of "fundamental learning conditions" whereby all schools are obligated to find a way to provide quality learning, especially to the most at-risk students. Accordingly, the MOET defined the following five standards for ChildFriendly Schools in Vietnam: (1) Proactively inclusive, seeking out and enabling the participation of all children, especially those who are differ ethnically, culturally, socioeconomically, and in individual ability; (2) Effective and relevant to children's needs regarding the knowledge and skills required for life and livelihood; (3) Be healthy and safe environments for, and to be protective of, children's emotional, psychological and physical well-being; (4) Gender-responsive in creating environments and capacities that foster equality; and (5) Actively engaged in, and enabling of, student, family and community participation in all aspects of school policy, management and support for children (MOET 2008).

In 2010, the MOET promoted the Action plan for the integration of climate change into the curriculum. The outputs of this project are (1) a set of textbooks, training and learning materials (curriculum and extracurricular activities) on climate change for all education and training levels; (2) a set of training materials for administrative officers, teachers, lecturers, students; (3) passing recommendations regarding the targets, contents, and solutions of the education sector to respond to 
9 The Practice of Education for Disaster Risk Reduction in Vietnam: Lessons Learned... 105

Table 9.1 Review of 14 DRRE projects and programs in schools carried out by various stakeholders during 2010-2020 in Vietnam

\begin{tabular}{|c|c|c|c|c|c|c|c|}
\hline \multirow[b]{2}{*}{ Name of projects/programs } & \multirow[b]{2}{*}{ Year } & \multirow[b]{2}{*}{ Organizations } & \multicolumn{5}{|c|}{$\begin{array}{l}\text { DRR-related } \\
\text { contents }\end{array}$} \\
\hline & & & (1) & (2) & (3) & (4) & (5) \\
\hline Child-friendly school & $\begin{array}{l}2008- \\
2009 \\
\text { (pilot) } \\
2013 \\
\text { (scale } \\
\text { up) }\end{array}$ & MOET & $\mathrm{Y}$ & $\mathrm{N}$ & $\mathrm{N}$ & $\mathrm{N}$ & $\mathrm{Y}$ \\
\hline $\begin{array}{l}\text { Strengthening the infrastructure } \\
\text { capacity of schools }\end{array}$ & 2008 & MOET & $\mathrm{Y}$ & $\mathrm{N}$ & $\mathrm{N}$ & $\mathrm{N}$ & $\mathrm{N}$ \\
\hline $\begin{array}{l}\text { Integration of climate change into } \\
\text { the curriculum }\end{array}$ & 2010 & MOET & $\mathrm{N}$ & $\mathrm{Y}$ & $\mathrm{N}$ & $\mathrm{N}$ & $\mathrm{N}$ \\
\hline $\begin{array}{l}\text { Raising community awareness and } \\
\text { community-based disaster risk } \\
\text { management }\end{array}$ & 2009 & MARD & $\mathrm{N}$ & $\mathrm{N}$ & $\mathrm{Y}$ & $\mathrm{Y}$ & $\mathrm{Y}$ \\
\hline $\begin{array}{l}\text { Communication programs using } \\
\text { multi-media to raise awareness about } \\
\text { climate change and DRR }\end{array}$ & 2011 & MOIT & $\mathrm{N}$ & $\mathrm{N}$ & $\mathrm{N}$ & $\mathrm{N}$ & $\mathrm{Y}$ \\
\hline $\begin{array}{l}\text { Introducing disaster preparedness in } \\
\text { primary schools }\end{array}$ & 2001 & $\begin{array}{l}\text { Vietnamese Red Cross } \\
\text { (VNRC) }\end{array}$ & Y & $\mathrm{Y}$ & $\mathrm{Y}$ & $\mathrm{Y}$ & $\mathrm{Y}$ \\
\hline $\begin{array}{l}\text { Adaptation to Climate change } \\
\text { through the Promotion of } \\
\text { Biodiversity }\end{array}$ & 2005 & GIZ Vietnam & $\mathrm{N}$ & $\mathrm{N}$ & $\mathrm{Y}$ & $\mathrm{N}$ & $\mathrm{Y}$ \\
\hline Integration of DRR into schools & 2008 & $\begin{array}{l}\text { Development Workshop } \\
\text { France (DWF) }\end{array}$ & $\mathrm{N}$ & $\mathrm{Y}$ & $\mathrm{Y}$ & $\mathrm{N}$ & $\mathrm{N}$ \\
\hline $\begin{array}{l}\text { Integrated disaster preparedness in } \\
\text { Thua Thien Hue Province }\end{array}$ & 2010 & VNRC & $\mathrm{N}$ & $\mathrm{N}$ & $\mathrm{Y}$ & $\mathrm{Y}$ & $\mathrm{Y}$ \\
\hline $\begin{array}{l}\text { Partnership for community action on } \\
\text { climate change }\end{array}$ & 2011 & $\begin{array}{l}\text { The Centre for } \\
\text { Development of } \\
\text { Community Initiative } \\
\text { and Environment }(C \& E)\end{array}$ & $\mathrm{N}$ & $\mathrm{N}$ & $\mathrm{Y}$ & $\mathrm{N}$ & $\mathrm{Y}$ \\
\hline $\begin{array}{l}\text { Capacity building for DRR } \\
\text { education for schools in Central } \\
\text { Vietnam }\end{array}$ & $\begin{array}{l}2011- \\
2013\end{array}$ & SEEDs Asia & $\mathrm{N}$ & $\mathrm{Y}$ & $\mathrm{Y}$ & $\mathrm{N}$ & $\mathrm{N}$ \\
\hline $\begin{array}{l}\text { Introducing climate change and } \\
\text { DRR education into the secondary } \\
\text { school system in Hanoi, Quang } \\
\text { Ninh, Hai Phong, Danang, and Ho } \\
\text { Chi Minh City }\end{array}$ & 2012 & Live and Learn Vietnam & $\mathrm{N}$ & $\mathrm{Y}$ & $\mathrm{Y}$ & $\mathrm{N}$ & $\mathrm{N}$ \\
\hline $\begin{array}{l}\text { Building resilience to climate change } \\
\text { in urban areas through integrated } \\
\text { education }\end{array}$ & $\begin{array}{l}2012- \\
2014\end{array}$ & $\begin{array}{l}\text { Institute for } \\
\text { Environmental and } \\
\text { Social Transition (ISET) }\end{array}$ & $\mathrm{N}$ & $\mathrm{Y}$ & $\mathrm{Y}$ & $\mathrm{N}$ & $\mathrm{N}$ \\
\hline
\end{tabular}

(continued) 
Table 9.1 (continued)

\begin{tabular}{|c|c|c|c|c|c|c|c|}
\hline \multirow[b]{2}{*}{ Name of projects/programs } & \multirow[b]{2}{*}{ Year } & \multirow[b]{2}{*}{ Organizations } & \multicolumn{5}{|c|}{$\begin{array}{l}\text { DRR-related } \\
\text { contents }\end{array}$} \\
\hline & & & (1) & (2) & (3) & (4) & (5) \\
\hline $\begin{array}{l}\text { Capacity building for disaster risk } \\
\text { reduction education for schools, } \\
\text { coastal communities in Quang Nam } \\
\text { province }\end{array}$ & $\begin{array}{l}2013- \\
2015\end{array}$ & SEEDs Asia & $\mathrm{N}$ & $\mathrm{Y}$ & $\mathrm{Y}$ & $\mathrm{N}$ & $\mathrm{N}$ \\
\hline
\end{tabular}

(1) School facilities/building safety

(2) Integration of DRR contents into the curriculum

(3) Extracurricular activities

(4) Injury prevention and swimming lessons

(4) Raising awareness- for parents/communities
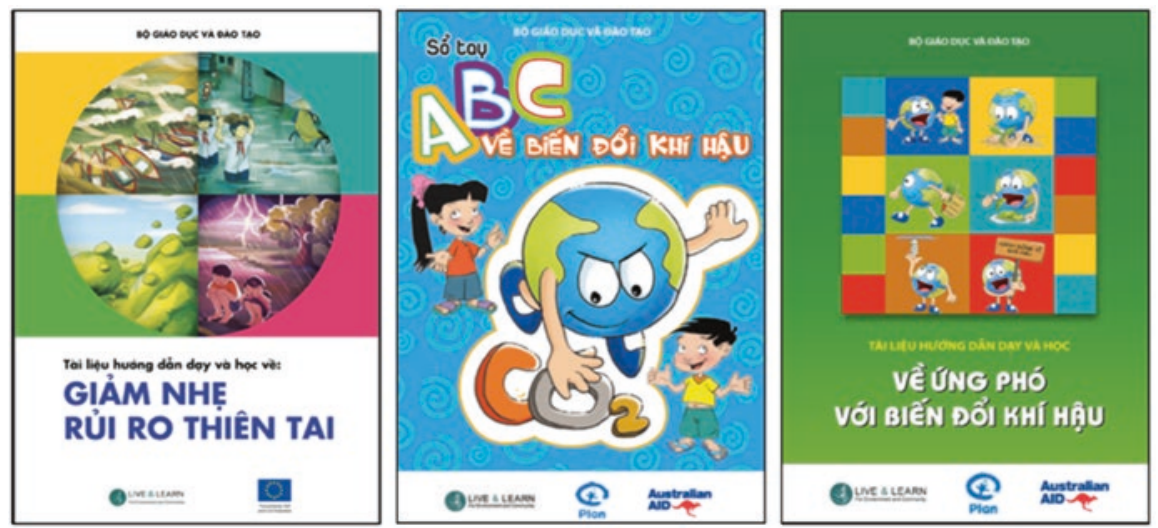

Fig. 9.3 Reference books on climate change and DRR approved and published by MOET in cooperation with various organizations

climate change in the future in order to develop new education programs; and reports on the experience of the education sector on climate change in other countries. The program has successfully achieved these specific aims. The MOET has collaborated with international organizations, NGOs, research institutes, and universities, such as the United Nations Children's Fund (UNICEF), Save the Children, Oxfam, and Humanitarian Aid and Civil Protection department (ECHO), the Joint Advocacy Network Initiative(JANI), to compose teaching and learning materials for teachers and students. In 2016, the MOET issued Guidelines for teaching climate change integration in the school curriculum, which focused specifically on Physics, Chemistry, Biology, Geography, and Technology. As a result, 63/63 provinces and cities implemented training courses on climate change and disaster education in schools (Fig. 9.3).

In 2011, as part of the climate change adaption program, MOET had committed to carry out tasks related to DRRE, including the introduction of education programs for children, which focus on responding and adapting to impacts of natural 
disasters and climate change through a new education development strategy for the period 2011-2015. In 2014, the MOET approved the project "Information and propaganda on climate change response and natural disaster prevention and control in schools in the period 2013-2020". The target audiences of the project include children, students, staff, teachers, members of the education sector, parents, and the community. In addition, several other programs and projects related to DRRE were carried by the MOET, such as inclusion of material on environmental protection into national education systems, the program "Strengthening the infrastructure capacity of schools," educational project targeting primary school children from economically disadvantaged communities, and a project to create access to secondary education for students in remote areas.

\subsubsection{Initiatives by Other Governmental Organizations}

In 2009, the Disaster Management Center, which falls under the auspices of the Ministry of Agriculture and Rural Development (MARD), promoted the program "Raising community awareness and community-based disaster risk management" following a promulgation of resolution No. 1002/QD-TTg by the Prime Minister in 2009. The program's main objectives are to raise community awareness and effectively organize a model for community-based disaster risk management for all levels and line agencies, particularly for the local authorities and residents at the village and commune levels. In 2011, the Ministry of Information and Technology (MOIT) developed multi-media communication programs (i.e., printed newspapers, radio, $\mathrm{TV}$, online newspapers) to raise awareness about climate change and DRR.

\subsubsection{Initiatives by International Organizations and Non-governmental Organizations}

In 2001, the Vietnam Red Cross Society (VNRC) emphasized disaster preparedness activities and implemented the program "Introducing Disaster Preparedness in Primary Schools." Since then, the program's activities have been replicated and are underway in all 21 of the most disaster-prone provinces in Vietnam. The aim of these programs was to mitigate the risk of disasters among school-going children who are among the most vulnerable to disasters. Targeted beneficiaries were teachers and children, as well as VNRC staff and government personnel. The program developed a new package of disaster preparedness training materials for Red Cross personnel, community leaders, teachers, and children. In addition, the program also elicited the active participation of relevant stakeholders, including teachers and children, in writing and finalizing the training and learning material (UNESCO 2009). The 12-month program aimed to assess needs and develop training materials for different targets including trainers, teachers, students (grade 4 and grade 5) and other relevant stakeholders in the selected communes. Recipient schools in disasterprone areas also organized inter-provincial competitions, including drama, quizzes, 
and painting competitions based on a guidance from disaster preparedness booklet. However, the program faced significant challenges in integrating a disaster preparedness component into the official training curricula due to the risk of overburdening school children. This challenge has not yet been overcome, although the VNRC insisted on providing disaster preparedness training until 2010 to teachers and children in eight coastal provinces in northern Vietnam with financial support from the Japanese Red Cross. As a result, the program and its subsequent replication have helped train 15,000 teachers and over 500,000 school children over the last 6 years (UNISDR 2007).

In 2005, the Deutsche Gesellschaft für Internationale Zusammenarbeit (GIZ) $\mathrm{GmbH}$ Vietnam carried out a project titled, "Adaptation to climate change through the promotion of biodiversity," which was financed by the German Federal Ministry for Environment, Nature Conservation, Nuclear Safety. It targeted communities, school teachers, and students, and tried to raise awareness of environmental and natural resource protection and biodiversity conservation. The primary approach were infused through the curriculum, specifically in Biology, Geography, Civic Education subjects and extracurricular activities, such as the Green and Clean Day, environmental drawing competitions, bird sanctuary visits, etc. As a result, the projects benefited teachers and students from grade 1-12 at 154 primary schools, 74 secondary schools, and 19 high schools in Bac Lieu Province.

In addition, an excellent example of integrating DRR into schools was implemented by Development Workshop France (DWF) in Hue Province in 2008. DWF worked as an important partner of many communes in Hue Province to strengthen existing public infrastructure and build safe, new schools, markets, and health facilities. At the village level, DWF accompanied with communes to build safe kindergartens and to strengthen primary schools so that children could learn about safety and safe construction techniques in a safe environment and take these principles back to their families. DWF also trained teachers about disaster prevention and ran workshops with children about disaster prevention and the child's role and needs before, during, and after disasters. Children were active in school and the community in promoting the vulnerability reduction message (DWF 2009).

Other projects implemented in Hue Province included, "Integrated Disaster Preparedness in Thua Thien Hue Province" which was undertaken by the German Red Cross (GRC) in cooperation with the Vietnamese Red Cross (VNRC) in 2010, "Partnership for community action on climate change" by the Centre for Development of Community Initiative and Environment (C\&E) and Global Action Plan International (GAP) in 2011. The project used schools as hubs for sustainability actions by households and communities, engaging teachers in civil society, linking schools and students with existing Vietnam government programs and priorities as well as existing Swedish government programs and priorities, which also helped to build partnerships between organizations. The activities included raising awareness among junior secondary schools' students to perform actions related to climate change, carrying out community outreach (family, school, neighbors) through undertaking Eco-team sustainable projects and activities, and establishing a "Green living model" at schools. The outcomes of the project included materials for 
community climate action through schools which were adopted for Vietnamese rural and urban contexts; teachers and youth leaders/facilitators received training to engage students in climate action; schools facilitated community climate activities; eco-team models were shared and advocated in project sites; and links to international development and learning about climate actions and education for sustainable development (ESD) were strengthened. Further, a household-level climate mitigation model has been developed, including teaching materials, materials for students, and a process to mainstream content into the curriculum. The project has benefited 3000 students, 500 junior secondary students, 93 teachers, 50 VNGO staff have participated and received training, and 20 education and sustainability decisionmakers have been trained in Hanoi, Thua Thien Hue, and Thai Binh.

In 2012, Live and Learn cooperated with the British Council in Vietnam and made considerable efforts to introduce climate change and DRR education into the secondary school system in Hanoi, Quang Ninh, Hai Phong, Danang, and Ho Chi Minh City. In addition to developing interactive multi-media materials (video and website) on "child/youth and climate change," the project also focused on the development of educational materials which could be used for adopting climate and disaster prevention actions in schools and communities. It also included various activities, such as training resource teachers and active youth clubs on climate change education; organizing extracurricular activities for students using the educational materials with the help from the resource teachers and volunteers of youth clubs; establishing a child-led forum at schools and in communities on climate change adaptation and mitigation; running competitions for every school that took part in the project to motivate them throughout the year and to identify good initiatives to support and potentially expand. Small grants were awarded for children-led initiatives on climate change adaptation and mitigation, and British Council schools were used as an online platform for promoting different initiatives.

In Da Nang, numerous projects and programs related to DRRE were carried out in the city. The project "Building resilience to climate change in urban areas through integrated education" was funded by the Rockefeller Foundation and implemented through a collaboration between the Institute for Environmental and Social Transition (ISET) and DoET Da Nang from 2012 through 2014. This project is widely considered to be a successful case study. Briefly, it started in January 2012 at three core schools (Ngo Quyen Primary School, Nguyen Van Linh Secondary School, and Hoa Vang High School) with the aim of developing a separate teaching syllabus on climate change and DRR based on the actual local situation. The project established a group of 30 core teachers to compile a syllabus for three subjects at the primary level (Geography, Biology, and Civics education). In addition, the project also targeted extracurricular activities in many forms, such as competitions, drills.

Another project that focused specifically on DRRE at the school level was carried out in Da Nang City in 2012. The project, which was implemented by SEEDS Asia and funded by JICA, aimed to build a disaster education network among schools and related organizations to enhance school DRRE in Da Nang city. The primary outcomes of the project were: (1) Core Schools for DRR (DRR Core 
schools) were established in every district of Da Nang city; (2) DRR Core Schools built a network on DRR; (3) More than one teacher at each school would be capable of conducting DRR classes; (4) Teachers and related governmental officials enhanced their knowledge of DRR education in Thua Thien Hue Province and Quang Nam Province; (5) A module for active teachers was developed; and (6) Experiences and outcomes were shared among a variety of disaster-related organization staff. As a result, seven core DRR schools were selected, 88 teachers were trained to become Training of trainers (ToT), 357 lessons and learning DRR classes were organized, and a working group comprising members from a variety of organizations (including MOET, BOET, vice-principal, and teachers of DRR core schools) was established (Ueda et al. 2016).

Other organizations from social organizations, private organizations, academia, and media have also contributed to the promotion of DRRE. In 2010, the Youth Union of the Information Technology Department at Hanoi University developed the software program "Awareness education for youngsters on climate change responses," which can be accessed both online and offline. This is an excellent resource for disseminating knowledge about climate change and disaster impacts for Youth Union members. The website "What can youngsters do about climate change?" provides activities, such as writing and drawing competitions with content reflecting the methods and responsibilities of individuals and organizations in response to climate change and disasters. Interestingly, the integration of climate and disaster issues has also been incorporated into the Mathematics curriculum. The project had been carried out by Kien Hung Secondary in Ha Noi with financial support from the World Bank. The project provided about 40 mathematics questions that were related to climate change topics. The results from the project have been shared with other schools and replicated in other provinces.

\subsection{Lessons Learned from a Decade of DRRE Implementation in Vietnam}

This review and analysis of the activities of 14 projects implemented in the period 2010-2020 in Vietnam have shown that many lessons related to the cohesion and role of local government have been learned through sustainable and innovative design initiatives.

One of the first lessons is that close cooperation between the local authorities and the Department of Education and Training during project implementation has been critical to a project's success. The project "Building resilience to climate change in urban areas through integrated education" that was implemented by ISET established a close relationship between the project management board, the local government, and the Da Nang Department of Education. This close relationship played a central role in facilitating and encouraging schools to participate both actively and proactively to achieve the project's aims. Furthermore, thanks to the involvement of 
the local government and the Department of Education and Training from the project design stage, the project received considerable support from government organizations throughout its implementation and the results of the project have been widely shared. Importantly, the lessons of the project have been reviewed thoroughly and many aspects have been integrated into the policies of local authorities to promote local DRR activities.

Secondly, it is clear that those projects that consider sustainability from the outset, i.e., from the project design stage, will achieve greater efficiency and sustainability. With the establishment of DRR core schools and working groups, the projects have promoted a strong connection between all stakeholders, creating space for them to learn from each other and to share what they have learned; indeed, such a connection is the key to the sustainability of a project. For example, although SEEDS Asia's project ended more than 5 years ago, some of the project's activities are still being implemented, especially at DRR core schools.

Another lesson is about incorporating indigenous knowledge when implementing the DRRE project. Vietnam has a long history of responding to disasters, and the local communities have prepared, responded, and recovered from these natural disasters using their experience and knowledge, which they have passed from one generation to the next. Indeed, these indigenous practices could be considered to be one of the first DRRE initiatives, and they are a valuable source of information and make an important contribution to both the community and school-based education initiative related to DRR.

Acknowledgement This research is funded by Vietnam National Foundation for Science and Technology Development (NAFOSTED) under grant number 507.01-2019.302.

\section{References}

David Eckstein VK (2019) The global climate risk index 2020, who suffers Most from extreme weather events? Weather-related loss events in 2018 and 1999 to 2018. Germanwatch, Berlin

DWF (2009) Developing Access to Safe and Good Quality Schools and Health Centres in Rural Central Viet Nam

Live and Learn Viet Nam (2012) Mapping climate change and disaster risk reduction education and communication in Viet Nam. Live and Learn, Plan Viet Nam, AID Australia

MOET (2008) Directive No. 40/2008/CT-BGDĐT dated 22/7/2008 on launching the emulation movement to build friendly schools, active students in high schools in the period 2008-2013. Ministry of Education and Training, Hanoi

MOET (2011) The action plan to implement the National Strategy on natural disaster mitigation, prevention and control in the education sector. Ministry of Education and training, Hanoi

MOET (2016) Guidelines for teaching climate change integration in the school curriculum. Ministry of Education and Training, Hanoi

MONRE (2016) Climate Change and Sea Level Rise Scenarios for Vietnam. https://www.preventionweb.net/files/11348_ClimateChangeSeaLevelScenariosforVi.pdf

Ueda Y, Matsumoto E, Nakagawa Y, Shaw R (2016) International cooperation: grassroots experience sharing in Vietnam. https://doi.org/10.1007/978-4-431-55982-5_13 
UNESCO (2009) Policy guidelines on inclusion in education. Paris, France. https://unesdoc. unesco.org/ark:/48223/pf0000177849

UNFCCC (2015) Adoption of the Paris Agreement, vol 21932. United Nations Framework Convention on Climate Change. http://unfccc.int/resource/docs/2015/cop21/eng/109r01.pdf

UNISDR (2004) Living with risk. A global review of disaster reduction initiatives, Strategy, vol 1. United Nations Inter-Agency Secretariat of the International Strategy for Disaster Reduction, Geneva

UNISDR (2005) Knowledge, innovation and education: building culture of safety and resilience. In: World conference on disaster reduction. United Nations/International Strategy for Disaster Reduction, Kobe

UNISDR (2007) Hyogo framework for action 2005-2015: Building the Resilience of Nations and Communities to Disasters. http://www.unisdr.org/files/1037_hyogoframeworkforactionenglish.pdf

Open Access This chapter is licensed under the terms of the Creative Commons Attribution 4.0 International License (http://creativecommons.org/licenses/by/4.0/), which permits use, sharing, adaptation, distribution and reproduction in any medium or format, as long as you give appropriate credit to the original author(s) and the source, provide a link to the Creative Commons license and indicate if changes were made.

The images or other third party material in this chapter are included in the chapter's Creative Commons license, unless indicated otherwise in a credit line to the material. If material is not included in the chapter's Creative Commons license and your intended use is not permitted by statutory regulation or exceeds the permitted use, you will need to obtain permission directly from the copyright holder. 